
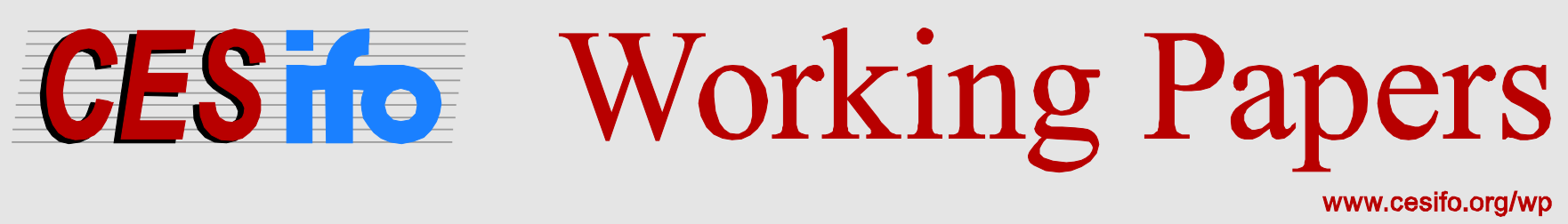

\title{
Tax Policy and Economic Growth: Does It Really Matter?
}

\author{
Donatella Baiardi \\ Paola Profeta \\ Riccardo Puglisi \\ Simona Scabrosetti
}

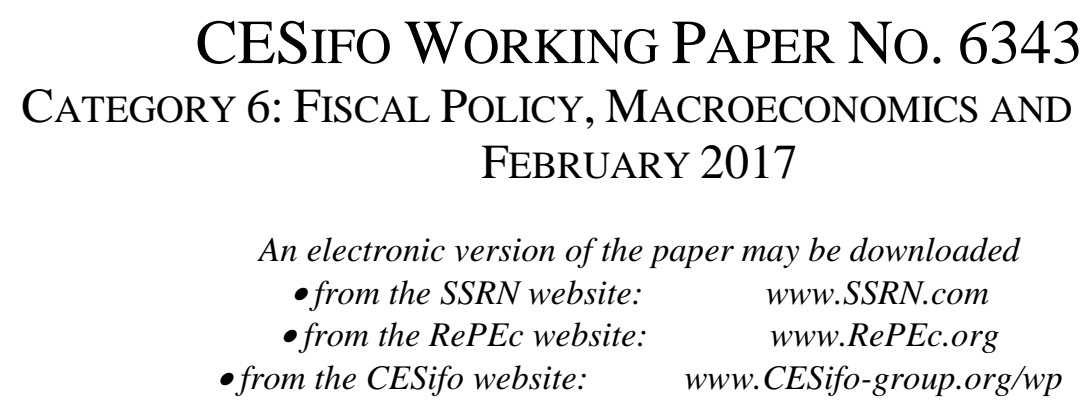




\title{
Tax Policy and Economic Growth: Does It Really Matter?
}

\begin{abstract}
We challenge the "OECD view" (Arnold et al. 2011) according to which a shift from direct to indirect taxation is associated with higher long-run economic growth. We study the relationships between per capita GDP, overall tax revenue and tax composition (in particular direct vs. indirect taxation). We can replicate the findings in Arnold et al. when focusing on the same sample of countries and time period, but not when adopting more cautious estimates of the standard errors. The results are not robust to adding countries and/or extending the time period under consideration. They also differ in the short- and long-run.
\end{abstract}

JEL-Codes: E620, H200, P500.

Keywords: economic growth, taxation, tax mix, OECD countries.

Donatella Baiardi Department of Economics University of Parma / Italy donatella.baiardi@unipr.it

Riccardo Puglisi* Department of Political and Social Sciences / University of Pavia / Italy riccardo.puglisi@unipv.it
Paola Profeta

Bocconi University

Milan / Italy

paola.profeta@unibocconi.it

Simona Scabrosetti

Department of Law

University of Pavia / Italy

simona.scabrosetti@unipv.it

*corresponding author

January 31, 2017

We thank Ethan Ilzetzki and seminar participants at the 2015 SIEP conference for useful comments. A special thanks to Jan Ditzen for help with his xtdcee2 Stata command. We also thank Paolo Longo for research assistance in data collection. 


\section{Introduction}

In a time of tight public finance conditions, frequently because of the high level of sovereign debts, there is a large and expanding debate on the effects of taxation on the level and growth of GDP. Scholars and policy makers alike -for a given level of fiscal pressure- are interested in whether the tax mix, i.e., the distribution of overall tax revenue across different tax sources, has a separate influence on the growth performance of a country. The most influential contribution, on which the OECD has based its policy prescriptions in the last years, is a paper by Arnold, Brys, Heady, Johansson, Schwellnus and Vartia published on the Economic Journal in 2011 (hereafter ABHJSV). For a sample of 21 OECD countries over the 1971-2004 period, they show that tax revenue is negatively and significantly associated with per capita GDP, while a shift from direct to indirect taxation is positively and significantly correlated with per capita GDP.

In this paper we replicate and test the robustness of these influential results. We first replicate the analysis in ABHJSV using the same sub-sample of OECD countries and the same time period. We estimate the relationships between tax burden, tax mix and per capita GDP, controlling for the standard growth determinants (fixed capital formation, human capital, population growth). Following ABHJSV, we adopt the panel version of an Error Correction Model (ECM) specification, i.e., the Pooled Mean Group Estimator (Pesaran et al., 1999). Our replication exercise confirms the findings of ABHJSV regarding the long-run partial correlations between per capita GDP, tax pressure and the tax mix. However, while ABHJSV do not report the short-run correlations between those variables, we show that in the short run the shift from direct to indirect taxation is not significantly correlated with per capita GDP. The only exception in the short run is a negative and significant correlation between taxes on immovable property and per capita GDP.

Second, we check whether -focusing on the same set of countries (21) and the same time period (1971-2004) - the results of ABHJSV are robust to using more conservative estimates of the standard errors, i.e., by clustering them at the country level (Bertrand et al. 2004). In this case the only result we can confirm is the negative and significant correlation between per capita GDP and tax revenue in the long run. All the other longrun correlations between the tax mix and GDP are not statistically significant at the ordinary confidence levels.

Since the data in ABHJSV stop well before the economic and financial crisis that started in 2008, it is particularly important to check whether their findings still hold on a longer time period which includes the crisis and the post-crisis period. Also, because of reasons of data availability, the analysis of a longer -and more recent- time period allows us to include a larger set of OECD countries. So, a third step in our analysis is to check the robustness of their results by extending their sample: more precisely, (i) we prolong the ABHJSV sample of countries to the most recent available years, i.e., up to 2014; (ii) we consider the full -and balanced-sample of 34 OECD countries during the 1995-2014 period; (iii) we restrict ourselves to the sample of OECD countries belonging to the Eurozone, again during the 1995-2014 period. ${ }^{1}$

In case (i) -when not clustering the standard errors at the country level- we can confirm the existence of a significant long-run negative correlation between the shift from indirect to direct taxes and GDP growth, which is however of the opposite sign in the

\footnotetext{
${ }^{1}$ See Xing (2012) for another robustness exercise which - on a sample restricted to only 17 OECD countries- similarly casts some doubts on the relationship between tax structure and growth.
} 
short run. Interestingly, property taxation is positively correlated with per capita GDP in the long run, while the opposite holds in the short run. On the other hand, the long-run correlation between tax revenue and GDP growth is only significant in one specification over five. However, when we cluster the standard errors at the country level, none of these long-run correlations is significant.

Regarding cases (ii) and (iii), neither the correlation of per capita GDP with tax revenue nor the ones with the tax mix are found to be statistically significant. This holds for both the long run and the short run, with and without clustered standard errors. The only noticeable exceptions to this lack of significant results are that -when not clustering the standard errors- a shift from personal to corporate taxation of income is positively and significantly correlated with GDP per capita in the long run, and that a shift from income to property taxes is negatively associated to per capita GDP in the short run. ${ }^{2}$

The paper is organized as follows: Section 2 presents the data and the empirical strategy, while Section 3 displays our results. Section 4 concludes.

\section{Data and Empirical Strategy}

We collect economic and fiscal data on the 34 countries that are currently members of the OECD, for the period from 1970 to $2014 .^{3}$

Economic variables include GDP at constant 2010 prices per head of population aged 15-64 years, the investment rate - proxied by the ratio of gross fixed capital formation to real GDP - the stock of human capital -proxied by the average number of years of schooling of the population aged between 15 and 64 years-, and the growth rate of the working age population. All variables come from OECD but the human capital variable which comes from the Barro-Lee (2013) dataset, recently updated up to 2016.

Fiscal data refer to total government and are taken from OECD revenue statistics. As in Arnold (2008), we organize these data as follows: income taxes include categories 1000 (taxes on income, profits and capital gains), 2000 (social security contributions) and 3000 (taxes on payroll and workforce); personal income taxes include categories 1100 (taxes on income, profits and capital gains of individuals), 2000 and $3000 .{ }^{4}$ Consumption and property taxes include categories 4000 (taxes on property), 5000 (taxes on good and services) and 6000 (other taxes); consumption taxes in turn include categories 5000 and 6000. Recurrent taxes on immovable property include categories 4100 (recurrent taxes on immovable property) and 4600 (other recurrent taxes on property), while other property taxes include categories from 4200 to 4500 (recurrent taxes on net wealth; estate inheritance and gift taxes; taxes on financial and capital transactions; non recurrent taxes on property). The overall tax burden is computed as the ratio of total tax revenue to GDP, while all the other fiscal variables are expressed as shares over total tax revenue. This allows to estimate the relationship between revenue-neutral tax shifts and GDP per capita. All data are available at yearly frequency.

\footnotetext{
${ }^{2}$ When clustering the standard errors the only mildly significant finding is the negative correlation between personal income taxation and per capita GDP in the Eurozone.

${ }^{3}$ The 34 OECD countries are: Australia, Austria, Belgium, Canada, Chile, Czech Republic, Denmark, Estonia, Finland, France, Germany, Greece, Hungary, Iceland, Ireland, Israel, Italy, Japan, Luxembourg, Mexico, Netherlands, New Zealand, Norway, Poland, Portugal, Slovakia, Slovenia, Korea (Rep. of), Spain, Sweden, Switzerland, Turkey, United Kingdom and United States.

${ }^{4}$ Corporate income taxes include category 1200 (taxes taxes on income, profits and capital gains of corporates).
} 
We follow the estimation methodology proposed by ABHJSV within a panel Error Correction framework:

$$
\begin{aligned}
\Delta \log Y_{i, t}= & a_{o, i}+\phi_{i} \log Y_{i, t-1}+a_{1, i} \log K_{i, t}+a_{2, i} \log H_{i, t}+a_{3, i} n_{i, t}+\sum a_{j, i} F I S C A L_{i, t}+F_{i}(t)+ \\
& b_{1, i} \Delta \log K_{i, t}+b_{2, i} \Delta \log H_{i, t}+b_{3, i} \Delta n_{i, t}+\sum b_{j, i} \Delta F I S C A L_{i, t}+\epsilon_{i, t}
\end{aligned}
$$

where, for each country $i$ and in each year $t, Y$ is real GDP per head of population, $K$ is the investment rate, $H$ is the stock of human capital, and $n$ is the growth rate of the working age population. FISCAL is a vector which refers to a set of tax structure variables: the overall tax burden, income taxes, personal income taxes, corporate income taxes, consumption and property taxes (taken together), consumption taxes, property taxes, recurrent taxes on immovable property and other property taxes. The parameters $a_{0}$ are a set of country fixed effects and $F_{i}(t)$ is a set of five-year dummies, whose coefficients are country specific. ${ }^{5}$ The terms with coefficients starting with " $a$ " and " $b$ " capture long-term and short-term dynamics respectively, while $\epsilon_{i, t}$ is the error term. ${ }^{6}$

Equation (1) is estimated by means of the Pooled Mean Group (PMG) estimator proposed by Pesaran et al. (1999), by allowing short-run coefficients, the speed of adjustment and error variances to differ across countries, but imposing homogeneity on long-run slope coefficients. Cross-sectional dependence is also taken into account, given that the countries analyzed are characterized by a high degree of economic integration. ${ }^{7}$

We perform four sets of estimates. First, we replicate the estimation proposed by ABHJSV (page F63) for the same sample of 21 OECD countries and the same time period 1971-2004. ${ }^{8}$ Second, we prolong the time period up to 2014, using the same sample of countries. Third, we perform our estimations on an expanded dataset composed by all the 34 OECD countries, for the period 1995-2014..$^{9}$ Finally, our empirical analysis is performed on a reduced set of countries, i.e., OECD countries that are current members of the Eurozone. ${ }^{10}$

\section{Empirical Results}

Results are presented in Tables 1-8. Odd-numbered tables show results with conventional standard errors, while in even-numbered tables -in order not to inflate the precision of our estimates because of potential within-group correlation of the error term- we cluster

\footnotetext{
${ }^{5}$ We include those country-specific five-year dummies to replicate the preferred specification by $\mathrm{AB}-$ HJSV (page F77).

${ }^{6}$ Following ABHJSV, estimates of steady state coefficients as well as of the parameters of the production function are computed as the ratio between $a$ and $\phi$. The estimation results presented in the paper contain the steady state effects calculated in this way.

${ }^{7}$ Results are obtained by means of the very recent Stata routine xtdcee2, proposed by Ditzen (2016), which estimates a heterogeneous coefficient model in a dynamic panel with dependence between crosssectional units. This routine is the evolution of the xtpmg Stata command (Blackburne and Frank, 2007) that was used by ABHJSV.

${ }^{8}$ These countries are: Australia, Austria, Belgium, Canada, Denmark, Finland, France, Germany (Western Germany, up to 1989 only), Greece, Ireland, Italy, Japan, Netherlands, New Zealand, Norway, Portugal, Spain, Sweden, Switzerland, United Kingdom and United States.

${ }^{9}$ Since for some countries OECD fiscal data are only available from 1995 we obtain a balanced panel by focusing on the 1995-2014 period.

${ }^{10}$ These countries are: Austria, Belgium, Estonia, Finland, France, Germany, Greece, Ireland, Italy, Luxembourg, Netherlands, Portugal, Slovakia, Slovenia and Spain. The time period is 1995-2014.
} 
the standard errors at the country level (Bertrand et al. 2004). Since the PMG estimator allows for country-specific short-run dynamics, there is a difference in the estimated conventional and clustered standard errors only for the long-run coefficients. Hence in odd-numbered tables we display both long-run and short-run results, while in evennumbered tables we only show the long-run ones.

\section{[Tables 1 and 2 about here]}

Table 1 replicates the estimation proposed by ABHJSV (page F63) for the same sample of 21 countries and the same time period 1971-2004. ${ }^{11}$ In line with what they found, we identify a negative and significant long-run correlation between the tax burden and per capita GDP, and a positive and significant long-run correlation between a shift from income to consumption and property taxes and growth. ${ }^{12}$ Differently from ABHJSV -who find a negative and significant correlation- a shift to corporate income taxation is not significantly correlated with per capita GDP.

Interestingly, in the short run (not reported by ABHJSV) the tax burden is negatively and significantly correlated with per capita GDP only in three specifications over five, while the only significant tax shift is the one towards taxes on immovable property, which in fact is negatively correlated with per capita GDP.

In Table 2 the only result robust to clustering is the negative relationship between overall tax revenue and per capita GDP in the long run. ${ }^{13}$

\section{[Tables 3 and 4 about here]}

Estimates in Tables 3 and 4 are based on the same sample of countries considered by ABHJSV, but the time period is prolonged up to 2014, with conventional and clustered standard errors respectively. In Table 3 only in one specification out of five the negative long-run correlation between the tax burden and per capita GDP is found to be (mildly) significant. We can confirm the positive long-run correlation of per capita GDP with a shift from income taxation to consumption and property taxation. However, when disentangling personal and corporate income taxes, a shift to the former is negatively associated with GDP, while the latter is positively correlated with GDP. Moving to the short run, the tax burden is negatively and significantly associated with GDP in all specifications, while correlations with the tax mix run contrary to what found in the long run: a shift from consumption and property taxation to income taxation (both personal and corporate) is positively and significantly correlated with GDP. ${ }^{14}$ In Table 4 we find that none of these correlations is significant.

\section{[Tables 5 and 6 about here]}

\footnotetext{
${ }^{11}$ We realized that for this time period OECD fiscal data are available also for Luxembourg, Korea (Rep. of) and Turkey. We check that results in Table 1 are confirmed when we include these countries, both one at a time and all together.

${ }^{12}$ When separating out consumption and property taxes, only a shift from income to property taxation is positively significantly correlated with GDP.

${ }^{13}$ One must notice that -when clustering the standard errors- the coefficient on the accumulation of physical capital in the long run is no longer statistically significant.

${ }^{14}$ The human capital variable enters with a positive sign in the regressions but is not statistically significant at ordinary confidence levels. This result is similar to Mankiw et al. (1992) and Islam (1995).
} 
Tables 5 and 6 show results for an expanded dataset composed by all the 34 OECD countries, for the period 1995-2014. We find that the tax burden is not significantly associated with economic growth in the long run, and that it is negatively associated with economic growth in the short run only in two out of five specifications. A shift from income to consumption and property taxes is not significantly related to per capita GDP in the long run, while the association between these two variables in the short run turns out to be negative -as already found in Table 3. Interestingly, a shift from consumption and property taxes to corporate taxation of income is positively and significantly correlated with GDP per capita in the long run. In Table 6 we cluster the standard errors at the country level. We do not find any significant relationship.

\section{[Tables 7 and 8 about here]}

Finally, Table 7 and Table 8 show results only for the OECD countries that are current members of the Eurozone, again for the period 1995-2014. In Table 7 we find a negative and significant correlation between the overall tax burden and per capita GDP only in one specification over five in the long run (column 2) and in two specifications in the short run (columns 1 and 5). Regarding the tax mix, the shift from consumption and property taxation to income is not statistically significant in the long run: in fact, it is a combination between a negative and significant correlation of per capita GDP with personal income taxation and a positive and significant correlation with corporate taxation. In the short run the only significant correlation we detect is the negative one between a shift from income to property taxes driven by immovable property and GDP, similarly to what found in Tables 1, 3 and 5. In Table 8, when we cluster the standard errors at the country level, the only significant result is that shifting away from personal taxes is related to higher economic growth.

\section{Conclusions}

This paper challenges the "OECD view", supported by the findings in ABHJSV, according to which in the long run the tax burden is negatively related with economic growth, while a shift from direct to indirect taxes is associated with higher economic growth. We show that these relationships hold true only in the long run and in the same sample of countries and the same time period considered by ABHJSV. However, these same findings are not robust to more cautious estimates of the standard errors, i.e., when clustering them at the country level. In this case, the only result which is confirmed is the negative relationship between tax revenue and economic growth, while the tax mix is no longer related to economic growth. Moreover, the results in ABHJSV are generally not robust to prolonging the time period under consideration, to enlarging the set of OECD countries, to focusing on the (possibly) more homogeneous Eurozone, and to adopting more cautious estimates of the standard errors.

In addition to replicating and checking the robustness of previous results, we also provide some interesting new findings about the differences in the long and short run correlations between fiscal policy and economic growth. Even in the same sample of countries and the same time period considered by ABHJSV, a tax shift from direct to indirect taxes has no relationship with economic growth in the short run. Though neglected by ABHJSV, short-run correlations might be very important when assessing the political feasibility of economic reforms, because voters are more likely to care about 
short - rather than long - run "effects" (Castanheira et al. 2012). This is particularly true in times of economic instability, as reflected by the growing consensus obtained by populist parties which base their platforms on short-term protection policies and on "pandering" to what people want (Canes-Wrone et al. 2001).

Interestingly, in the short run we find a negative and significant correlation between a shift from income taxes to recurrent taxes on immovable property and economic growth, which runs contrary to the standard "OECD view" and the recommendations by the European Commission itself (European Commission Services 2006). ${ }^{15}$

From a theoretical viewpoint, the differences we find in the short-run and long-run correlations of economic growth and taxation might be connected with the differential salience of taxes along different time horizons (Chetty et al. 2009). This is a promising avenue for future research.

\footnotetext{
${ }^{15}$ In fact, to date those policy recommendations on efficient tax shifts have been only very partially implemented by developed countries. On EU countries see e.g. Bernardi (2013).
} 


\section{References}

[1] Arnold, J. M. (2008). Do Tax Structures Affect Aggregate Economic Growth? Empirical Evidence from a Panel of OECD Countries. OECD Economics Department Working Paper 643.

[2] Arnold, J. M., Brys, B., Heady, C., Johansson, A., Schwellnus, C. and Vartia, L. (2011). Tax Policy for Economic Recovery and Growth. The Economic Journal, 121 (February), F59-F80.

[3] Barro, R. J., Lee, J. W. (2013). A New Data Set of Educational Attainment in the World, 1950â2010. Journal of Development Economics, 104, 184-198.

[4] Bernardi, L. (2013). Recent findings regarding the shift from direct to indirect taxation in the EA-17. Rivista di diritto finanziario e scienza delle finanze, 4, 233-256.

[5] Bertrand, M. Duflo, E. and Mullainathan, S. (2004). How Much Should We Trust Differences-In-Differences Estimates? Quarterly Journal of Economics, 119(1), 249275 .

[6] Blackburne, E. F., III, Frank, M. W. (2007). Estimation of Nonstationary Heterogeneous Panels. The Stata Journal, 7(2), 197-208.

[7] Canes-Wrone, B., Herron, M. C. and Shotts, K. W. (2001). "Leadership and Pandering: A Theory of Executive Policymaking." American Journal of Political Science, $45,532-550$.

[8] Chetty, R., Looney, A., and Kroft, K. (2009). Salience and Taxation: Theory and Evidence. American Economic Review, 99(4), $1145 a ̂ 1177$.

[9] Castanheira, M., Nicodéme, G. and Profeta, P. (2012). On the political economics of tax reforms: survey and empirical assessment. International Tax and Public Finance, 19, 598 â624.

[10] Ditzen, J. (2016). xtdcce: Estimating Dynamic Common Correlated Effects in Stata. SEEC Discussion Paper Series No 8, July 2016 Available at http://seec.hw.ac.uk/

[11] European Commission Services (DG TAXUD) (2006). 'Macroeconomic Effects of a Shift from Direct to Indirect Taxation: a Simulation for 15 EU Member States.' Note presented at the 72nd Meeting of the OECD Working Party No. 2 on Tax Policy Analysis and Tax Statistics, Paris, 14-16 November 2006.

[12] Islam, N. (1995). Growth Empirics: A Panel Data Approach. Quarterly Journal of Economics, 110(4), 1127-1170.

[13] Mankiw, N. G., Romer, D. and Weill, D. N. (1992). A Contribution to the Empirics of Economic Growth. Quarterly Journal of Economics, 107(2), 407-437.

[14] Pesaran, M., Shin, Y., and Smith, R. (1999). Pooled Mean Group Estimation of Dynamic Heterogeneous Panels. Journal of the American Statistical Association, 94(446), 621-634.

[15] Xing, J. (2012). Tax Structure and Growth: How Robust is the Empirical Evidence? Economics Letters, 117(1), 379-382. 
Table 1: Taxation and GDP per capita: 21 OECD countries, 1971-2004.

\begin{tabular}{|c|c|c|c|c|c|}
\hline & $(1)$ & $(2)$ & (3) & $(4)$ & $(5)$ \\
\hline \multicolumn{6}{|l|}{ Long-run parameters } \\
\hline Convergence parameter $(\phi)$ & $\begin{array}{l}-0.173^{* * *} \\
(0.037)\end{array}$ & $\begin{array}{c}-0.216^{* * *} \\
(0.039)\end{array}$ & $\begin{array}{c}-0.170^{* * *} \\
(0.037)\end{array}$ & $\begin{array}{c}-0.179^{* * *} \\
(0.038)\end{array}$ & $\begin{array}{c}-0.148^{* * *} \\
(0.038)\end{array}$ \\
\hline Physical capital $\left(a_{1 i}\right)$ & $\begin{array}{c}0.220 * * * \\
(0.074)\end{array}$ & $\begin{array}{c}0.174^{* * *} \\
(0.064)\end{array}$ & $\begin{array}{c}0.217^{* * *} \\
(0.075)\end{array}$ & $\begin{array}{c}0.244^{* * * *} \\
(0.072)\end{array}$ & $\begin{array}{c}0.282^{* * *} \\
(0.091)\end{array}$ \\
\hline Human capital $\left(a_{2 i}\right)$ & $\begin{array}{c}1.483^{* * *} * \\
(0.204)\end{array}$ & $\begin{array}{l}1.499^{* * *} * \\
(0.164)\end{array}$ & $\begin{array}{l}1.024 * * * \\
(0.177)\end{array}$ & $\begin{array}{l}0.991^{* * * *} \\
(0.170)\end{array}$ & $\begin{array}{l}0.911 * * * \\
(0.218)\end{array}$ \\
\hline Population growth $\left(a_{3 i}\right)$ & $\begin{array}{l}-13.253^{* * *} \\
(3.789)\end{array}$ & $\begin{array}{l}-8.335^{* * * *} \\
(2.496)\end{array}$ & $\begin{array}{c}-13.450 * * * \\
(3.889)\end{array}$ & $\begin{array}{l}-12.184^{* * *} \\
(3.583)\end{array}$ & $\begin{array}{c}-14.070^{* * * *} \\
(4.776)\end{array}$ \\
\hline Overall tax burden $\left(a_{4 i}\right)$ & $\begin{array}{l}-0.018^{* * *} \\
(0.005)\end{array}$ & $\begin{array}{l}-0.016^{* * * *} \\
(0.004)\end{array}$ & $\begin{array}{c}-0.018^{* * *} \\
(0.005)\end{array}$ & $\begin{array}{c}-0.015^{* * *} \\
(0.005)\end{array}$ & $\begin{array}{c}-0.016^{* *} \\
(0.006)\end{array}$ \\
\hline Income taxes $\left(a_{5 i}\right)$ & $\begin{array}{c}-0.011^{* *} \\
(0.004)\end{array}$ & - & - & - & - \\
\hline Personal income taxes $\left(a_{6 i}\right)$ & - & $\begin{array}{c}-0.011^{* * *} \\
(0.003)\end{array}$ & - & - & - \\
\hline Corporate income taxes $\left(a_{7 i}\right)$ & - & $\begin{array}{c}0.005 \\
(0.004)\end{array}$ & - & - & - \\
\hline Consumption and property taxes $\left(a_{8 i}\right)$ & - & - & $\begin{array}{c}0.010^{* *} \\
(0.004)\end{array}$ & - & - \\
\hline Consumption taxes $\left(a_{9 i}\right)$ & - & - & - & $\begin{array}{c}0.006 \\
(0.004)\end{array}$ & $\begin{array}{c}0.007 \\
(0.007)\end{array}$ \\
\hline Property taxes $\left(a_{10 i}\right)$ & - & - & - & $\begin{array}{l}0.020^{* * *} \\
(0.01)\end{array}$ & - \\
\hline Property taxes: immovable property $\left(a_{11 i}\right)$ & - & - & - & - & $\begin{array}{l}0.034^{*} \\
(0.019)\end{array}$ \\
\hline Property taxes: others $\left(a_{12 i}\right)$ & - & - & - & - & $\begin{array}{c}0.020^{* *} \\
(0.009)\end{array}$ \\
\hline \multicolumn{6}{|l|}{ Short-run parameters } \\
\hline Overall tax burden $\left(b_{4 i}\right)$ & $\begin{array}{c}-0.002 * \\
(0.001)\end{array}$ & $\begin{array}{l}-0.001 \\
(0.001)\end{array}$ & $\begin{array}{c}-0.001 * \\
(0.001)\end{array}$ & $\begin{array}{l}-0.002 \\
(0.001)\end{array}$ & $\begin{array}{l}-0.003^{* * *} \\
(0.001)\end{array}$ \\
\hline Income taxes $\left(b_{5 i}\right)$ & $\begin{array}{c}0.001 \\
(0.000)\end{array}$ & - & $\begin{array}{c}- \\
(0.001)\end{array}$ & - & - \\
\hline Personal income taxes $\left(b_{6 i}\right)$ & - & $\begin{array}{c}0.000 \\
(0.000)\end{array}$ & - & - & - \\
\hline Corporate income taxes $\left(b_{7 i}\right)$ & - & $\begin{array}{c}0.001 \\
(0.000)\end{array}$ & - & - & - \\
\hline Consumption and property taxes $\left(b_{8 i}\right)$ & - & - & $\begin{array}{l}-0.000 \\
(0.000)\end{array}$ & - & - \\
\hline Consumption taxes $\left(b_{9 i}\right)$ & - & - & - & $\begin{array}{c}0.000 \\
(0.000)\end{array}$ & $\begin{array}{c}0.000 \\
(0.001)\end{array}$ \\
\hline Property taxes $\left(b_{10 i}\right)$ & - & - & - & $\begin{array}{l}-0.002 \\
(0.002)\end{array}$ & - \\
\hline Property taxes: immovable property $\left(b_{11 i}\right)$ & - & - & - & - & $\begin{array}{c}-0.025^{*} \\
(0.014)\end{array}$ \\
\hline Property taxes: others $\left(b_{12 i}\right)$ & - & - & - & - & $\begin{array}{c}0.003 \\
(0.002)\end{array}$ \\
\hline Five-year dummy variables & Yes & Yes & Yes & Yes & Yes \\
\hline Constant & $\begin{array}{c}0.110 * * * \\
(0.005)\end{array}$ & $\begin{array}{c}0.131 * * * \\
(0.008)\end{array}$ & $\begin{array}{c}0.109^{* * *} \\
(0.004)\end{array}$ & $\begin{array}{c}0.109 * * * \\
(0.004)\end{array}$ & $\begin{array}{l}0.094 * * * \\
(0.004)\end{array}$ \\
\hline Observations & 693 & 675 & 693 & 693 & 693 \\
\hline R-squared & 0.81 & 0.82 & 0.81 & 0.82 & 0.84 \\
\hline Number of groups & 21 & 21 & 21 & 21 & 21 \\
\hline $\begin{array}{l}\text { Revenue-neutrality } \\
\text { achieved by adjusting }\end{array}$ & $\begin{array}{l}\text { Consumption and } \\
\text { Property taxes }\end{array}$ & $\begin{array}{l}\text { Consumption and } \\
\text { Property taxes }\end{array}$ & $\begin{array}{l}\text { Income } \\
\text { taxes }\end{array}$ & $\begin{array}{l}\text { Income } \\
\text { taxes }\end{array}$ & $\begin{array}{l}\text { Income } \\
\text { taxes }\end{array}$ \\
\hline
\end{tabular}

Notes: Estimates are obtained by means of the Pooled Mean Group estimator proposed by Pesaran et al. (1999) within a panel error-correction framework. All columns include measures of the accumulation of physical and human capital and population growth as basic growth determinants as well as the overall tax burden as a control variable. They also report the effects of various revenue-neutral tax shifts. All economic variables are in logs. All the variables in the short run are in first difference. The short-run coefficients related to shifts. All economic variables are in logs. All the variables in the short run are in first difference. The short-run coefficients related to
economic variables $\left(b_{1 i}, b_{2 i}\right.$ and $\left.b_{3 i}\right)$ are not reported. Standard errors are shown in parentheses: $*$ significant at 10 per cent; $* *$ significant economic variables $\left(b_{1 i}, b_{2 i}\right.$ and $\left.b_{3 i}\right)$ are not 
Table 2: Taxation and GDP per capita: 21 OECD countries, 1971-2004, clustered standard errors.

\begin{tabular}{|c|c|c|c|c|c|}
\hline & (1) & $(2)$ & (3) & (4) & $(5)$ \\
\hline Convergence parameter $(\phi)$ & $\begin{array}{c}-0.173^{* *} \\
(0.078)\end{array}$ & $\begin{array}{c}-0.216^{* *} \\
(0.099)\end{array}$ & $\begin{array}{c}-0.170^{* *} \\
(0.079)\end{array}$ & $\begin{array}{c}-0.179^{* *} \\
(0.082)\end{array}$ & $\begin{array}{c}-0.148^{*} \\
(0.078)\end{array}$ \\
\hline Physical capital $\left(a_{1 i}\right)$ & $\begin{array}{c}0.220 \\
(0.169)\end{array}$ & $\begin{array}{c}0.174 \\
(0.143)\end{array}$ & $\begin{array}{c}0.217 \\
(0.172)\end{array}$ & $\begin{array}{c}0.244 \\
(0.167)\end{array}$ & $\begin{array}{c}0.282 \\
(0.217)\end{array}$ \\
\hline Human capital $\left(a_{2 i}\right)$ & $\begin{array}{c}1.483^{* * *} \\
(0.391)\end{array}$ & $\begin{array}{c}1.499^{* * *} \\
(0.352)\end{array}$ & $\begin{array}{l}1.024^{* * * *} \\
(0.282)\end{array}$ & $\begin{array}{l}0.991^{* * *} \\
(0.276)\end{array}$ & $\begin{array}{c}0.911^{* * *} \\
(0.348)\end{array}$ \\
\hline Population growth $\left(a_{3 i}\right)$ & $\begin{array}{c}-13.253^{*} \\
(6.781)\end{array}$ & $\begin{array}{l}-8.335^{*} \\
(4.953)\end{array}$ & $\begin{array}{c}-13.450^{*} \\
(7.010)\end{array}$ & $\begin{array}{c}-12.184^{*} \\
(6.704)\end{array}$ & $\begin{array}{c}-14.070^{*} \\
(8.531)\end{array}$ \\
\hline Overall tax burden $\left(a_{4 i}\right)$ & $\begin{array}{c}-0.018^{* *} \\
(0.008)\end{array}$ & $\begin{array}{c}-0.016 * * \\
(0.007)\end{array}$ & $\begin{array}{c}-0.018^{* *} \\
(0.009)\end{array}$ & $\begin{array}{c}-0.015^{* *} \\
(0.008)\end{array}$ & $\begin{array}{l}-0.016 \\
(0.010)\end{array}$ \\
\hline Income taxes $\left(a_{5 i}\right)$ & $\begin{array}{l}-0.011 \\
(0.009)\end{array}$ & - & - & - & - \\
\hline Personal income taxes $\left(a_{6 i}\right)$ & - & $\begin{array}{l}-0.011 \\
(0.009)\end{array}$ & - & - & - \\
\hline Corporate income taxes $\left(a_{7 i}\right)$ & - & $\begin{array}{c}0.005 \\
(0.006)\end{array}$ & - & - & - \\
\hline Consumption and property taxes $\left(a_{8 i}\right)$ & - & - & $\begin{array}{c}0.010 \\
(0.009)\end{array}$ & - & - \\
\hline Consumption taxes $\left(a_{9 i}\right)$ & - & - & - & $\begin{array}{c}0.006 \\
(0.009)\end{array}$ & $\begin{array}{c}0.007 \\
(0.009)\end{array}$ \\
\hline Property taxes $\left(a_{10 i}\right)$ & - & - & - & $\begin{array}{c}0.020 \\
(0.021)\end{array}$ & - \\
\hline Property taxes: immovable property $\left(a_{11 i}\right)$ & - & - & - & - & $\begin{array}{c}0.034 \\
(0.030)\end{array}$ \\
\hline Property taxes: others $\left(a_{12 i}\right)$ & - & - & - & - & $\begin{array}{c}0.020 \\
(0.027)\end{array}$ \\
\hline Observations & 693 & 675 & 693 & 693 & 693 \\
\hline R-squared & 0.806 & 0.821 & 0.806 & 0.820 & 0.839 \\
\hline Number of groups & 21 & 21 & 21 & 21 & 21 \\
\hline $\begin{array}{l}\text { Revenue-neutrality } \\
\text { achieved by adjusting }\end{array}$ & $\begin{array}{l}\text { Consumption and } \\
\text { Property taxes }\end{array}$ & $\begin{array}{l}\text { Consumption and } \\
\text { Property taxes }\end{array}$ & $\begin{array}{l}\text { Income } \\
\text { taxes }\end{array}$ & $\begin{array}{l}\text { Income } \\
\text { taxes }\end{array}$ & $\begin{array}{l}\text { Income } \\
\text { taxes }\end{array}$ \\
\hline
\end{tabular}

Notes: Estimates are obtained by means of the Pooled Mean Group estimator proposed by Pesaran et al. (1999) within a panel error-correction framework. All columns include measures of the accumulation of physical and human capital and population growth as basic growth determinants as well as the overall tax burden as a control variable. They also report the effects of various revenue-neutral tax shifts. All economic variables are in logs. Clustered standard errors are shown in parentheses: $*$ significant at 10 per cent; ** significant at 5 per cent; *** significant at 1 per cent. 
Table 3: Taxation and GDP per capita: 21 OECD countries, 1971-2014.

\begin{tabular}{|c|c|c|c|c|c|}
\hline & (1) & $(2)$ & (3) & (4) & (5) \\
\hline \multicolumn{6}{|l|}{ Long-run parameters } \\
\hline Convergence parameter $(\phi)$ & $\begin{array}{l}-0.122 * * * \\
(0.022)\end{array}$ & $\begin{array}{c}-0.122^{* * * *} \\
(0.021)\end{array}$ & $\begin{array}{c}-0.122 * * * \\
(0.022)\end{array}$ & $\begin{array}{c}-0.130 * * * \\
(0.022)\end{array}$ & $\begin{array}{l}-0.106 * * * \\
(0.022)\end{array}$ \\
\hline Physical capital $\left(a_{1 i}\right)$ & $\begin{array}{l}0.199^{* *} \\
(0.100)\end{array}$ & $\begin{array}{c}0.161 \\
(0.103)\end{array}$ & $\begin{array}{l}0.197^{* *} \\
(0.100)\end{array}$ & $\begin{array}{l}0.227^{* *} \\
(0.096)\end{array}$ & $\begin{array}{l}0.213^{*} \\
(0.125)\end{array}$ \\
\hline Human capital $\left(a_{2 i}\right)$ & $\begin{array}{l}-0.437 \\
(0.544)\end{array}$ & $\begin{array}{l}-0.385 \\
(0.518)\end{array}$ & $\begin{array}{l}-0.443 \\
(0.546)\end{array}$ & $\begin{array}{l}-0.345 \\
(0.516)\end{array}$ & $\begin{array}{l}-0.413 \\
(0.638)\end{array}$ \\
\hline Population growth $\left(a_{3 i}\right)$ & $\begin{array}{c}-13.635^{* * *} \\
(3.716)\end{array}$ & $\begin{array}{c}-10.351^{* * *} \\
(3.363)\end{array}$ & $\begin{array}{c}-13.704^{* * *} \\
(3.733)\end{array}$ & $\begin{array}{l}-11.722^{* * *} \\
(3.386)\end{array}$ & $\begin{array}{c}-12.913^{* * *} \\
(4.251)\end{array}$ \\
\hline Overall tax burden $\left(a_{4 i}\right)$ & $\begin{array}{l}-0.005 \\
(0.006)\end{array}$ & $\begin{array}{l}-0.011^{*} \\
(0.006)\end{array}$ & $\begin{array}{l}-0.006 \\
(0.006)\end{array}$ & $\begin{array}{l}-0.005 \\
(0.006)\end{array}$ & $\begin{array}{l}-0.008 \\
(0.008)\end{array}$ \\
\hline Income taxes $\left(a_{5 i}\right)$ & $\begin{array}{c}-0.013^{* *} \\
(0.006)\end{array}$ & - & - & - & - \\
\hline Personal income taxes $\left(a_{6 i}\right)$ & - & $\begin{array}{l}-0.018 * * * \\
(0.006)\end{array}$ & - & - & - \\
\hline Corporate income taxes $\left(a_{7 i}\right)$ & - & $\begin{array}{c}0.015^{* *} \\
(0.007)\end{array}$ & - & - & - \\
\hline Consumption and property taxes $\left(a_{8 i}\right)$ & - & - & $\begin{array}{c}0.011^{* *} \\
(0.006)\end{array}$ & - & - \\
\hline Consumption taxes $\left(a_{9 i}\right)$ & - & - & - & $\begin{array}{c}0.007 \\
(0.006)\end{array}$ & $\begin{array}{c}0.005 \\
(0.007)\end{array}$ \\
\hline Property taxes $\left(a_{10 i}\right)$ & - & - & - & $\begin{array}{c}0.020^{* *} \\
(0.010)\end{array}$ & - \\
\hline Property taxes: immovable property $\left(a_{11 i}\right)$ & - & - & - & - & $\begin{array}{l}-0.003 \\
(0.021)\end{array}$ \\
\hline Property taxes: others $\left(a_{12 i}\right)$ & - & - & - & - & $\begin{array}{c}0.034^{* *} \\
(0.015)\end{array}$ \\
\hline \multicolumn{6}{|l|}{ Short-run parameters } \\
\hline Overall tax burden $\left(b_{4 i}\right)$ & $\begin{array}{l}-0.004 * * * \\
(0.001)\end{array}$ & $\begin{array}{l}-0.004^{* * *} \\
(0.001)\end{array}$ & $\begin{array}{l}-0.004 * * * \\
(0.001)\end{array}$ & $\begin{array}{l}-0.004^{* * *} \\
(0.001)\end{array}$ & $\begin{array}{l}-0.005 * * * \\
(0.001)\end{array}$ \\
\hline Income taxes $\left(b_{5 i}\right)$ & $\begin{array}{c}0.003^{* * *} \\
(0.001)\end{array}$ & - & - & - & - \\
\hline Personal income taxes $\left(b_{6 i}\right)$ & - & $\begin{array}{c}0.001 * * \\
(0.001)\end{array}$ & - & - & - \\
\hline Corporate income taxes $\left(b_{7 i}\right)$ & - & $\begin{array}{c}0.003^{* * *} \\
(0.001)\end{array}$ & - & - & - \\
\hline Consumption and property taxes $\left(b_{8 i}\right)$ & - & - & $\begin{array}{l}-0.003^{* * *} \\
(0.001)\end{array}$ & - & - \\
\hline Consumption taxes $\left(b_{9 i}\right)$ & - & - & - & $\begin{array}{c}-0.002^{* *} \\
(0.001)\end{array}$ & $\begin{array}{c}-0.001 * * \\
(0.001)\end{array}$ \\
\hline Property taxes $\left(b_{10 i}\right)$ & - & - & - & $\begin{array}{l}-0.004^{*} \\
(0.002)\end{array}$ & - \\
\hline Property taxes: immovable property $\left(b_{11 i}\right)$ & - & - & - & - & $\begin{array}{c}-0.017^{* *} \\
(0.008)\end{array}$ \\
\hline Property taxes: others $\left(b_{12 i}\right)$ & - & - & - & - & $\begin{array}{c}0.002 \\
(0.003)\end{array}$ \\
\hline Five-year dummy variables & Yes & Yes & Yes & Yes & Yes \\
\hline Constant & $\begin{array}{c}0.604 * * * \\
(0.010)\end{array}$ & $\begin{array}{c}0.635^{* * *} \\
(0.011)\end{array}$ & $\begin{array}{c}0.462^{* * *} \\
(0.010)\end{array}$ & $\begin{array}{c}0.456^{* * *} \\
(0.009)\end{array}$ & $\begin{array}{c}0.416^{* * *} \\
(0.008)\end{array}$ \\
\hline Observations & 900 & 881 & 900 & 900 & 899 \\
\hline R-squared & 0.828 & 0.855 & 0.828 & 0.837 & 0.853 \\
\hline Number of groups & 21 & 21 & 21 & 21 & 21 \\
\hline $\begin{array}{l}\text { Revenue-neutrality } \\
\text { achieved by adjusting }\end{array}$ & $\begin{array}{l}\text { Consumption and } \\
\text { Property taxes }\end{array}$ & $\begin{array}{l}\text { Consumption and } \\
\text { Property taxes }\end{array}$ & $\begin{array}{l}\text { Income } \\
\text { taxes }\end{array}$ & $\begin{array}{l}\text { Income } \\
\text { taxes }\end{array}$ & $\begin{array}{l}\text { Income } \\
\text { taxes }\end{array}$ \\
\hline
\end{tabular}

Notes: Estimates are obtained by means of the Pooled Mean Group estimator proposed by Pesaran et al. (1999) within a panel error-correction framework. All columns include measures of the accumulation of physical and human capital and population growth as basic growth determinants as well as the overall tax burden as a control variable. They also report the effects of various revenue-neutral tax shifts. All economic variables are in logs. All the variables in the short run are in first difference. The short-run coefficients related to shifts. All economic variables are in logs. All the variables in the short run are in first difference. The short-run coefficients related to
economic variables $\left(b_{1 i}, b_{2 i}\right.$ and $\left.b_{3 i}\right)$ are not reported. Standard errors are shown in parentheses: $*$ significant at 10 per cent; $* *$ significant economic variables $\left(b_{1 i}, b_{2 i}\right.$ and $\left.b_{3 i}\right)$ are not 
Table 4: Taxation and GDP per capita: 21 OECD countries, 1971-2014, clustered standard errors.

\begin{tabular}{|c|c|c|c|c|c|}
\hline & (1) & (2) & (3) & (4) & $(5)$ \\
\hline Convergence parameter $(\phi)$ & $\begin{array}{l}-0.122 * * * \\
(0.038)\end{array}$ & $\begin{array}{l}-0.122^{* * *} \\
(0.035)\end{array}$ & $\begin{array}{l}-0.122^{* * *} \\
(0.039)\end{array}$ & $\begin{array}{l}-0.130 * * * \\
(0.039)\end{array}$ & $\begin{array}{c}-0.106 * * * \\
(0.036)\end{array}$ \\
\hline Physical capital $\left(a_{1 i}\right)$ & $\begin{array}{c}0.199 \\
(0.214)\end{array}$ & $\begin{array}{c}0.161 \\
(0.215)\end{array}$ & $\begin{array}{c}0.197 \\
(0.214)\end{array}$ & $\begin{array}{c}0.227 \\
(0.210)\end{array}$ & $\begin{array}{c}0.213 \\
(0.275)\end{array}$ \\
\hline Human capital $\left(a_{2 i}\right)$ & $\begin{array}{l}-0.437 \\
(0.724)\end{array}$ & $\begin{array}{l}-0.385 \\
(0.811)\end{array}$ & $\begin{array}{l}-0.443 \\
(0.732)\end{array}$ & $\begin{array}{l}-0.345 \\
(0.690)\end{array}$ & $\begin{array}{l}-0.413 \\
(0.857)\end{array}$ \\
\hline Population growth $\left(a_{3 i}\right)$ & $\begin{array}{c}-13.635^{* *} \\
(5.943)\end{array}$ & $\begin{array}{c}-10.351^{* * *} \\
(3.715)\end{array}$ & $\begin{array}{c}-13.704^{* *} \\
(5.899)\end{array}$ & $\begin{array}{c}-11.722^{* *} \\
(4.720)\end{array}$ & $\begin{array}{c}-12.913^{* *} \\
(5.775)\end{array}$ \\
\hline Overall tax burden $\left(a_{4 i}\right)$ & $\begin{array}{l}-0.005 \\
(0.008)\end{array}$ & $\begin{array}{l}-0.011 \\
(0.009)\end{array}$ & $\begin{array}{l}-0.006 \\
(0.008)\end{array}$ & $\begin{array}{l}-0.005 \\
(0.008)\end{array}$ & $\begin{array}{l}-0.008 \\
(0.009)\end{array}$ \\
\hline Income taxes $\left(a_{5 i}\right)$ & $\begin{array}{l}-0.013 \\
(0.010)\end{array}$ & - & - & - & - \\
\hline Personal income taxes $\left(a_{6 i}\right.$ & - & $\begin{array}{l}-0.018 \\
(0.013)\end{array}$ & - & - & - \\
\hline Corporate income taxes $\left(a_{7 i}\right)$ & - & $\begin{array}{c}0.015 \\
(0.012)\end{array}$ & - & - & - \\
\hline Consumption and property taxes $\left(a_{8 i}\right)$ & - & - & $\begin{array}{c}0.011 \\
(0.010)\end{array}$ & - & - \\
\hline Consumption taxes $\left(a_{9 i}\right)$ & - & - & - & $\begin{array}{c}0.007 \\
(0.009)\end{array}$ & $\begin{array}{c}0.005 \\
(0.011)\end{array}$ \\
\hline Property taxes $\left(a_{10 i}\right)$ & - & - & - & $\begin{array}{c}0.020 \\
(0.025)\end{array}$ & \\
\hline Property taxes: immovable property $\left(a_{11 i}\right)$ & - & - & - & - & $\begin{array}{l}-0.003 \\
(0.027)\end{array}$ \\
\hline Property taxes: others $\left(a_{12 i}\right)$ & - & - & - & - & $\begin{array}{c}0.034 \\
(0.044)\end{array}$ \\
\hline Observations & 900 & 881 & 900 & 900 & 899 \\
\hline R-squared & 0.828 & 0.855 & 0.828 & 0.837 & 0.853 \\
\hline Number of groups & 21 & 21 & 21 & 21 & 21 \\
\hline $\begin{array}{l}\text { Revenue-neutrality } \\
\text { achieved by adjusting }\end{array}$ & $\begin{array}{l}\text { Consumption and } \\
\text { Property taxes }\end{array}$ & $\begin{array}{l}\text { Consumption and } \\
\text { Property taxes }\end{array}$ & $\begin{array}{l}\text { Income } \\
\text { taxes }\end{array}$ & $\begin{array}{l}\text { Income } \\
\text { taxes }\end{array}$ & $\begin{array}{l}\text { Income } \\
\text { taxes }\end{array}$ \\
\hline
\end{tabular}

Notes: Estimates are obtained by means of the Pooled Mean Group estimator proposed by Pesaran et al. (1999) within a panel error-correction framework. All columns include measures of the accumulation of physical and human capital and population growth as basic growth determinants as well as the overall tax burden as a control variable. They also report the effects of various revenue-neutral tax shifts. All economic variables are in logs. Clustered standard errors are shown in parentheses: * significant at 10 per cent; ** significant at 5 per cent; *** significant at 1 per cent. 
Table 5: Taxation and GDP per capita: all 34 OECD countries, 1995-2014.

\begin{tabular}{|c|c|c|c|c|c|}
\hline & (1) & $(2)$ & (3) & $(4)$ & (5) \\
\hline \multicolumn{6}{|l|}{ Long-run parameters } \\
\hline Convergence parameter $(\phi)$ & $\begin{array}{l}-0.181 * * * \\
(0.045)\end{array}$ & $\begin{array}{l}-0.159 * * * \\
(0.047)\end{array}$ & $\begin{array}{c}-0.144^{* * *} \\
(0.040)\end{array}$ & $\begin{array}{c}-0.117^{* *} \\
(0.048)\end{array}$ & $\begin{array}{c}-0.104^{* *} \\
(0.049)\end{array}$ \\
\hline Physical capital $\left(a_{1 i}\right)$ & $\begin{array}{c}0.645^{* * *} \\
(0.163)\end{array}$ & $\begin{array}{l}0.711 * * * \\
(0.202)\end{array}$ & $\begin{array}{l}0.735^{* * *} \\
(0.202)\end{array}$ & $\begin{array}{l}0.752^{* * *} \\
(0.278)\end{array}$ & $\begin{array}{c}0.593^{* *} \\
(0.288)\end{array}$ \\
\hline Human capital $\left(a_{2 i}\right)$ & $\begin{array}{c}0.643^{* * *} \\
(0.224)\end{array}$ & $\begin{array}{l}0.988 * * * \\
(0.269)\end{array}$ & $\begin{array}{l}0.589^{*} \\
(0.343)\end{array}$ & $\begin{array}{c}0.923^{* *} \\
(0.396)\end{array}$ & $\begin{array}{l}1.020^{* *} \\
(0.480)\end{array}$ \\
\hline Population growth $\left(a_{3 i}\right)$ & $\begin{array}{l}-6.521^{*} \\
(3.668)\end{array}$ & $\begin{array}{l}-8.254^{*} \\
(4.294)\end{array}$ & $\begin{array}{l}-8.334^{*} \\
(4.603)\end{array}$ & $\begin{array}{l}-10.283 \\
(6.597)\end{array}$ & $\begin{array}{l}-9.820 \\
(7.474)\end{array}$ \\
\hline Overall tax burden $\left(a_{4 i}\right)$ & $\begin{array}{l}-0.000 \\
(0.007)\end{array}$ & $\begin{array}{l}-0.003 \\
(0.008)\end{array}$ & $\begin{array}{c}0.002 \\
(0.009)\end{array}$ & $\begin{array}{l}-0.004 \\
(0.012)\end{array}$ & $\begin{array}{l}-0.005 \\
(0.014)\end{array}$ \\
\hline Income taxes $\left(a_{5 i}\right)$ & $\begin{array}{c}0.002 \\
(0.005)\end{array}$ & - & - & - & - \\
\hline Personal income taxes $\left(a_{6 i}\right)$ & - & $\begin{array}{l}-0.014 \\
(0.009)\end{array}$ & - & - & - \\
\hline Corporate income taxes $\left(a_{7 i}\right)$ & - & $\begin{array}{c}0.022^{* *} \\
(0.010)\end{array}$ & - & - & - \\
\hline Consumption and Property taxes $\left(a_{8 i}\right)$ & - & - & $\begin{array}{l}-0.000 \\
(0.006)\end{array}$ & - & - \\
\hline Consumption taxes $\left(a_{9 i}\right)$ & - & - & - & $\begin{array}{l}-0.010 \\
(0.009)\end{array}$ & $\begin{array}{l}-0.003 \\
(0.011)\end{array}$ \\
\hline Property taxes $\left(a_{10 i}\right)$ & - & - & - & $\begin{array}{c}0.019 \\
(0.017)\end{array}$ & - \\
\hline Property taxes: immovable property $\left(a_{11 i}\right)$ & - & - & - & - & $\begin{array}{l}-0.049 \\
(0.046)\end{array}$ \\
\hline Property taxes: others $\left(a_{12 i}\right)$ & - & - & - & - & $\begin{array}{c}0.018 \\
(0.019)\end{array}$ \\
\hline \multicolumn{6}{|l|}{ Short-run parameters } \\
\hline Overall tax burden $\left(b_{4 i}\right)$ & $\begin{array}{l}-0.003 \\
(0.002)\end{array}$ & $\begin{array}{l}-0.005^{* * *} \\
(0.002)\end{array}$ & $\begin{array}{l}-0.003 \\
(0.002)\end{array}$ & $\begin{array}{l}-0.002 \\
(0.002)\end{array}$ & $\begin{array}{c}-0.004^{* *} \\
(0.002)\end{array}$ \\
\hline Income taxes $\left(b_{5 i}\right)$ & $\begin{array}{c}0.003 \\
(0.002)\end{array}$ & - & - & - & - \\
\hline Personal income taxes $\left(b_{6 i}\right)$ & - & $\begin{array}{l}-0.000 \\
(0.002)\end{array}$ & - & - & - \\
\hline Corporate income taxes $\left(b_{7 i}\right)$ & - & $\begin{array}{c}0.003 \\
(0.002)\end{array}$ & - & - & - \\
\hline Consumption and Property taxes $\left(b_{8 i}\right)$ & - & - & $\begin{array}{c}-0.003^{*} \\
(0.002)\end{array}$ & - & - \\
\hline Consumption taxes $\left(b_{9 i}\right)$ & - & - & - & $\begin{array}{l}-0.002 * \\
(0.001)\end{array}$ & $\begin{array}{l}-0.002 \\
(0.001)\end{array}$ \\
\hline Property taxes $\left(b_{10} i\right)$ & - & - & - & $\begin{array}{c}-0.016^{* * *} \\
(0.008)\end{array}$ & - \\
\hline Property taxes: immovable property $\left(b_{11 i}\right)$ & - & - & - & - & $\begin{array}{c}-0.100^{* * *} \\
(0.037)\end{array}$ \\
\hline Property taxes: others $\left(b_{12 i}\right)$ & - & - & - & - & $\begin{array}{c}0.007 \\
(0.008)\end{array}$ \\
\hline Five-year dummy variables & Yes & Yes & Yes & Yes & Yes \\
\hline Constant & $\begin{array}{c}0.085^{* * *} \\
(0.016)\end{array}$ & $\begin{array}{c}0.050^{* * *} \\
(0.016)\end{array}$ & $\begin{array}{c}0.051^{* * *} \\
(0.017)\end{array}$ & $\begin{array}{l}-0.004 \\
(0.013)\end{array}$ & $\begin{array}{c}0.019 \\
(0.012)\end{array}$ \\
\hline Observations & 671 & 631 & 671 & 671 & 670 \\
\hline R-squared & 0.883 & 0.915 & 0.880 & 0.903 & 0.924 \\
\hline Number of groups & 34 & 32 & 34 & 34 & 34 \\
\hline $\begin{array}{l}\text { Revenue-neutrality } \\
\text { achieved by adjusting }\end{array}$ & $\begin{array}{l}\text { Consumption and } \\
\text { Property taxes }\end{array}$ & $\begin{array}{l}\text { Consumption and } \\
\text { Property taxes }\end{array}$ & $\begin{array}{l}\text { Income } \\
\text { taxes }\end{array}$ & $\begin{array}{l}\text { Income } \\
\text { taxes }\end{array}$ & $\begin{array}{l}\text { Income } \\
\text { taxes }\end{array}$ \\
\hline
\end{tabular}

Notes: Estimates are obtained by means of the Pooled Mean Group estimator proposed by Pesaran et al. (1999) within a panel error-correction framework. All columns include measures of the accumulation of physical and human capital and population growth as basic growth determinants as well as the overall tax burden as a control variable. They also report the effects of various revenue-neutral tax shifts. All economic variables are in logs. All the variables in the short run are in first difference. The short-run coefficients related to economic variables $\left(b_{1 i}, b_{2 i}\right.$ and $\left.b_{3 i}\right)$ are not reported. Standard errors are shown in parentheses: $*$ significant at 10 per cent; $* *$ significant at 5 per cent; *** significant at 1 per cent. 
Table 6: Taxation and GDP per capita: 34 OECD countries, 1995-2014, clustered standard errors.

\begin{tabular}{|c|c|c|c|c|c|}
\hline & (1) & $(2)$ & (3) & $(4)$ & $(5)$ \\
\hline Convergence parameter $(\phi)$ & $\begin{array}{c}-0.181^{* *} \\
(0.092)\end{array}$ & $\begin{array}{c}-0.159^{* *} \\
(0.074)\end{array}$ & $\begin{array}{c}-0.181^{* *} \\
(0.086)\end{array}$ & $\begin{array}{l}-0.117 \\
(0.085)\end{array}$ & $\begin{array}{c}-0.104 \\
(0.094)\end{array}$ \\
\hline Physical capital $\left(a_{1 i}\right)$ & $\begin{array}{l}0.645^{*} \\
(0.380)\end{array}$ & $\begin{array}{l}0.711^{*} \\
(0.384)\end{array}$ & $\begin{array}{l}0.639^{*} \\
(0.157)\end{array}$ & $\begin{array}{c}0.752 \\
(0.613)\end{array}$ & $\begin{array}{c}0.593 \\
(0.712)\end{array}$ \\
\hline Human capital $\left(a_{2 i}\right)$ & $\begin{array}{l}0.643^{*} \\
(0.368)\end{array}$ & $\begin{array}{l}0.988^{* *} \\
(0.419)\end{array}$ & $\begin{array}{c}0.711 \\
(0.496)\end{array}$ & $\begin{array}{c}0.923 \\
(0.775)\end{array}$ & $\begin{array}{c}1.020 \\
(1.100)\end{array}$ \\
\hline Population growth $\left(a_{3 i}\right)$ & $\begin{array}{l}-6.521 \\
(5.333)\end{array}$ & $\begin{array}{l}-8.254 \\
(6.135)\end{array}$ & $\begin{array}{l}-6.546 \\
(4.827)\end{array}$ & $\begin{array}{r}-10.283 \\
(9.642)\end{array}$ & $\begin{array}{c}-9.820 \\
(13.726)\end{array}$ \\
\hline Overall tax burden $\left(a_{4 i}\right)$ & $\begin{array}{l}-0.000 \\
(0.011)\end{array}$ & $\begin{array}{l}-0.003 \\
(0.017)\end{array}$ & $\begin{array}{c}0.000 \\
(0.011)\end{array}$ & $\begin{array}{l}-0.004 \\
(0.019)\end{array}$ & $\begin{array}{l}-0.005 \\
(0.026)\end{array}$ \\
\hline Income taxes $\left(a_{5 i}\right)$ & $\begin{array}{c}0.002 \\
(0.010)\end{array}$ & - & - & - & - \\
\hline Personal income taxes $\left(a_{6 i}\right.$ & - & $\begin{array}{l}-0.014 \\
(0.015)\end{array}$ & - & - & - \\
\hline Corporate income taxes $\left(a_{7 i}\right)$ & - & $\begin{array}{c}0.022 \\
(0.022)\end{array}$ & - & - & - \\
\hline Consumption and property taxes $\left(a_{8 i}\right)$ & - & - & $\begin{array}{l}-0.001 \\
(0.009)\end{array}$ & - & - \\
\hline Consumption taxes $\left(a_{9 i}\right)$ & - & - & - & $\begin{array}{c}-0.010 \\
(0.019)\end{array}$ & $\begin{array}{c}-0.003 \\
(0.024)\end{array}$ \\
\hline Property taxes $\left(a_{10 i}\right)$ & - & - & - & $\begin{array}{c}0.019 \\
(0.031)\end{array}$ & - \\
\hline Property taxes: immovable property $\left(a_{11 i}\right)$ & - & - & - & - & $\begin{array}{l}-0.049 \\
(0.074)\end{array}$ \\
\hline Property taxes: others $\left(a_{12 i}\right)$ & - & - & - & - & $\begin{array}{l}0.018 \\
(0.044)\end{array}$ \\
\hline Observations & 671 & 631 & 671 & 671 & 670 \\
\hline R-squared & 0.880 & 0.920 & 0.880 & 0.900 & 0.920 \\
\hline Number of groups & 34 & 34 & 34 & 34 & 34 \\
\hline $\begin{array}{l}\text { Revenue-neutrality } \\
\text { achieved by adjusting }\end{array}$ & $\begin{array}{l}\text { Consumption and } \\
\text { Property taxes }\end{array}$ & $\begin{array}{l}\text { Consumption and } \\
\text { Property taxes }\end{array}$ & $\begin{array}{l}\text { Income } \\
\text { taxes }\end{array}$ & $\begin{array}{l}\text { Income } \\
\text { taxes }\end{array}$ & $\begin{array}{l}\text { Income } \\
\text { taxes }\end{array}$ \\
\hline
\end{tabular}

Notes: Estimates are obtained by means of the Pooled Mean Group estimator proposed by Pesaran et al. (1999) within a panel error-correction framework. All columns include measures of the accumulation of physical and human capital and population growth as basic growth determinants as well as the overall tax burden as a control variable. They also report the effects of various revenue-neutral tax shifts. All economic variables are in logs. Clustered standard errors are shown in parentheses: * significant at 10 per cent; ** significant at 5 per cent; *** significant at 1 per cent. 
Table 7: Taxation and GDP per capita: Eurozone countries, 1995-2014.

\begin{tabular}{|c|c|c|c|c|c|}
\hline & (1) & $(2)$ & (3) & $(4)$ & (5) \\
\hline \multicolumn{6}{|l|}{ Long-run parameters } \\
\hline Convergence parameter $(\phi)$ & $\begin{array}{c}-0.182^{* * *} \\
(0.044)\end{array}$ & $\begin{array}{c}-0.185^{* * *} \\
(0.045)\end{array}$ & $\begin{array}{l}-0.180^{* * *} \\
(0.045)\end{array}$ & $\begin{array}{c}-0.164^{* * *} \\
(0.048)\end{array}$ & $\begin{array}{l}-0.091^{*} \\
(0.051)\end{array}$ \\
\hline Physical capital $\left(a_{1 i}\right)$ & $\begin{array}{c}0.827^{* * *} \\
(0.220)\end{array}$ & $\begin{array}{l}0.479^{* *} \\
(0.204)\end{array}$ & $\begin{array}{c}0.827 * * * \\
(0.227)\end{array}$ & $\begin{array}{c}0.807 * * * \\
(0.256)\end{array}$ & $\begin{array}{l}1.137^{*} \\
(0.645)\end{array}$ \\
\hline Human capital $\left(a_{2 i}\right)$ & $\begin{array}{l}1.214 \\
(0.913)\end{array}$ & $\begin{array}{c}0.475 \\
(0.853)\end{array}$ & $\begin{array}{l}1.225 \\
(0.926)\end{array}$ & $\begin{array}{c}1.161 \\
(1.048)\end{array}$ & $\begin{array}{c}0.542 \\
(2.022)\end{array}$ \\
\hline Population growth $\left(a_{3 i}\right)$ & $\begin{array}{l}-11.419^{* *} \\
(5.602)\end{array}$ & $\begin{array}{l}-9.264^{*} \\
(4.997)\end{array}$ & $\begin{array}{l}-11.713^{* *} \\
(5.725)\end{array}$ & $\begin{array}{c}-13.111^{*} \\
(6.925)\end{array}$ & $\begin{array}{l}-20.723 \\
(16.179)\end{array}$ \\
\hline Overall tax burden $\left(a_{4 i}\right)$ & $\begin{array}{l}-0.013 \\
(0.014)\end{array}$ & $\begin{array}{l}-0.023^{*} \\
(0.013)\end{array}$ & $\begin{array}{l}-0.014 \\
(0.014)\end{array}$ & $\begin{array}{l}-0.017 \\
(0.016)\end{array}$ & $\begin{array}{l}-0.004 \\
(0.032)\end{array}$ \\
\hline Income taxes $\left(a_{5 i}\right)$ & $\begin{array}{l}-0.012 \\
(0.009)\end{array}$ & - & - & - & - \\
\hline Personal income taxes $\left(a_{6 i}\right)$ & - & $\begin{array}{c}-0.033^{* * *} \\
(0.012)\end{array}$ & - & - & - \\
\hline Corporate income taxes $\left(a_{7 i}\right)$ & - & $\begin{array}{c}0.029^{* *} \\
(0.012)\end{array}$ & - & - & - \\
\hline Consumption and property taxes $\left(a_{8 i}\right)$ & - & - & $\begin{array}{c}0.010 \\
(0.010)\end{array}$ & - & - \\
\hline Consumption taxes $\left(a_{9 i}\right)$ & - & - & - & $\begin{array}{c}0.001 \\
(0.014)\end{array}$ & $\begin{array}{c}0.022 \\
(0.033)\end{array}$ \\
\hline Property taxes $\left(a_{10 i}\right)$ & - & - & - & $\begin{array}{c}0.022 \\
(0.016)\end{array}$ & - \\
\hline Property taxes: immovable property $\left(a_{11 i}\right)$ & - & - & - & - & $\begin{array}{c}0.053 \\
(0.111)\end{array}$ \\
\hline Property taxes: others $\left(a_{12 i}\right)$ & - & - & - & - & $\begin{array}{c}0.025 \\
(0.029)\end{array}$ \\
\hline \multicolumn{6}{|l|}{ Short-run parameters } \\
\hline Overall tax burden $\left(b_{4 i}\right)$ & $\begin{array}{c}-0.004 * \\
(0.002)\end{array}$ & $\begin{array}{l}-0.003 \\
(0.002)\end{array}$ & $\begin{array}{l}-0.003 \\
(0.002)\end{array}$ & $\begin{array}{l}-0.004 \\
(0.003)\end{array}$ & $\begin{array}{c}-0.006^{* *} \\
(0.003)\end{array}$ \\
\hline Income taxes $\left(b_{5 i}\right)$ & $\begin{array}{c}0.002 \\
(0.002)\end{array}$ & - & - & - & - \\
\hline Personal income taxes $\left(b_{6 i}\right)$ & - & $\begin{array}{c}0.002 \\
(0.002)\end{array}$ & - & - & - \\
\hline Corporate income taxes $\left(b_{7 i}\right)$ & - & $\begin{array}{l}-0.000 \\
(0.003)\end{array}$ & - & - & - \\
\hline Consumption and property taxes $\left(b_{8 i}\right)$ & - & - & $\begin{array}{l}-0.002 \\
(0.002)\end{array}$ & - & - \\
\hline Consumption taxes $\left(b_{9 i}\right)$ & - & - & - & $\begin{array}{l}-0.002 \\
(0.003)\end{array}$ & $\begin{array}{l}-0.000 \\
(0.002)\end{array}$ \\
\hline Property taxes $\left(b_{10} i\right)$ & - & - & - & $\begin{array}{c}-0.025^{*} \\
(0.013)\end{array}$ & - \\
\hline Property taxes: immovable property $\left(b_{11 i}\right)$ & - & - & - & - & $\begin{array}{c}-0.178^{* *} \\
(0.068)\end{array}$ \\
\hline Property taxes: others $\left(b_{12 i}\right)$ & - & - & - & - & $\begin{array}{c}0.006 \\
(0.009)\end{array}$ \\
\hline Five-year dummy variables & Yes & Yes & Yes & Yes & Yes \\
\hline Constant & $\begin{array}{l}-0.016 \\
(0.025)\end{array}$ & $\begin{array}{c}0.726^{* * *} \\
(0.024)\end{array}$ & $\begin{array}{l}-0.215^{* * *} \\
(0.025)\end{array}$ & $\begin{array}{l}-0.100 * * * \\
(0.021)\end{array}$ & $\begin{array}{c}-0.119^{* * *} \\
(0.013)\end{array}$ \\
\hline Observations & 296 & 295 & 296 & 296 & 295 \\
\hline R-squared & 0.893 & 0.930 & 0.892 & 0.910 & 0.929 \\
\hline Number of groups & 15 & 15 & 15 & 15 & 15 \\
\hline $\begin{array}{l}\text { Revenue-neutrality } \\
\text { achieved by adjusting }\end{array}$ & $\begin{array}{l}\text { Consumption and } \\
\text { Property taxes }\end{array}$ & $\begin{array}{l}\text { Consumption and } \\
\text { Property taxes }\end{array}$ & $\begin{array}{l}\text { Income } \\
\text { taxes }\end{array}$ & $\begin{array}{l}\text { Income } \\
\text { taxes }\end{array}$ & $\begin{array}{l}\text { Income } \\
\text { taxes }\end{array}$ \\
\hline
\end{tabular}

Notes: Estimates are obtained by means of the Pooled Mean Group estimator proposed by Pesaran et al. (1999) within a panel error-correction framework. All columns include measures of the accumulation of physical and human capital and population growth a basic growth determinants as well as the overall tax burden as a control variable. They also report the effects of various revenue-neutral tax shifts. All economic variables are in logs. All the variables in the short run are in first difference. The short-run coefficients related to economic variables $\left(b_{1 i}, b_{2 i}\right.$ and $\left.b_{3 i}\right)$ are not reported. Standard errors are shown in parentheses: ${ }^{*}$ significant at 10 per cent; $* *$ significant at 5 per cent; *** significant at 1 per cent. 
Table 8: Taxation and GDP per capita: Eurozone countries, 1995-2014, clustered standard errors.

\begin{tabular}{|c|c|c|c|c|c|}
\hline & (1) & $(2)$ & (3) & (4) & $(5)$ \\
\hline Convergence parameter $(\phi)$ & $\begin{array}{c}-0.185^{* * *} \\
(0.064)\end{array}$ & $\begin{array}{c}-0.185^{* * *} \\
(0.063)\end{array}$ & $\begin{array}{c}-0.180^{* * *} \\
(0.065)\end{array}$ & $\begin{array}{c}-0.164^{* *} \\
(0.074)\end{array}$ & $\begin{array}{c}-0.091 \\
(0.089)\end{array}$ \\
\hline Physical capital $\left(a_{1 i}\right)$ & $\begin{array}{l}0.827^{*} \\
(0.453)\end{array}$ & $\begin{array}{c}0.479 \\
(0.493)\end{array}$ & $\begin{array}{l}0.827^{*} \\
(0.480)\end{array}$ & $\begin{array}{c}0.807 \\
(0.551)\end{array}$ & $\begin{array}{c}1.137 \\
(1.314)\end{array}$ \\
\hline Human capital $\left(a_{2 i}\right)$ & $\begin{array}{c}1.214 \\
(0.783)\end{array}$ & $\begin{array}{c}0.475 \\
(0.792)\end{array}$ & $\begin{array}{c}1.225 \\
(0.767)\end{array}$ & $\begin{array}{c}1.161 \\
(0.983)\end{array}$ & $\begin{array}{c}0.542 \\
(2.229)\end{array}$ \\
\hline Population growth $\left(a_{3 i}\right)$ & $\begin{array}{l}-11.419 \\
(7.953)\end{array}$ & $\begin{array}{l}-9.264 \\
(7.479)\end{array}$ & $\begin{array}{r}-11.713 \\
(8.140)\end{array}$ & $\begin{array}{l}-13.111 \\
(9.907)\end{array}$ & $\begin{array}{r}-20.723 \\
(23.647)\end{array}$ \\
\hline Overall tax burden $\left(a_{4 i}\right)$ & $\begin{array}{l}-0.013 \\
(0.015)\end{array}$ & $\begin{array}{l}-0.023 \\
(0.020)\end{array}$ & $\begin{array}{l}-0.014 \\
(0.014)\end{array}$ & $\begin{array}{l}-0.017 \\
(0.019)\end{array}$ & $\begin{array}{l}-0.004 \\
(0.059)\end{array}$ \\
\hline Income taxes $\left(a_{5 i}\right)$ & $\begin{array}{l}-0.012 \\
(0.015)\end{array}$ & - & - & - & - \\
\hline Personal income taxes $\left(a_{6 i}\right.$ & - & $\begin{array}{c}-0.033^{*} \\
(0.019)\end{array}$ & - & - & - \\
\hline Corporate income taxes $\left(a_{7 i}\right)$ & - & $\begin{array}{c}0.029 \\
(0.030)\end{array}$ & - & - & - \\
\hline Consumption and property taxes $\left(a_{8 i}\right)$ & - & - & $\begin{array}{c}0.010 \\
(0.015)\end{array}$ & - & - \\
\hline Consumption taxes $\left(a_{9 i}\right)$ & - & - & - & $\begin{array}{c}0.001 \\
(0.026)\end{array}$ & $\begin{array}{c}0.022 \\
(0.073)\end{array}$ \\
\hline Property taxes $\left(a_{10 i}\right)$ & - & - & - & $\begin{array}{c}0.022 \\
(0.029)\end{array}$ & - \\
\hline Property taxes: immovable property $\left(a_{11 i}\right)$ & - & - & - & - & $\begin{array}{c}0.053 \\
(0.137)\end{array}$ \\
\hline Property taxes: others $\left(a_{12 i}\right)$ & - & - & - & - & $\begin{array}{l}0.025 \\
(0.049)\end{array}$ \\
\hline Observations & 296 & 295 & 296 & 296 & 295 \\
\hline R-squared & 0.890 & 0.930 & 0.890 & 0.910 & 0.930 \\
\hline Number of groups & 15 & 15 & 15 & 15 & 15 \\
\hline $\begin{array}{l}\text { Revenue-neutrality } \\
\text { achieved by adjusting }\end{array}$ & $\begin{array}{l}\text { Consumption and } \\
\text { Property taxes }\end{array}$ & $\begin{array}{l}\text { Consumption and } \\
\text { Property taxes }\end{array}$ & $\begin{array}{l}\text { Income } \\
\text { taxes }\end{array}$ & $\begin{array}{l}\text { Income } \\
\text { taxes }\end{array}$ & $\begin{array}{l}\text { Income } \\
\text { taxes }\end{array}$ \\
\hline
\end{tabular}

Notes: Estimates are obtained by means of the Pooled Mean Group estimator proposed by Pesaran et al. (1999) within a panel error-correction framework. All columns include measures of the accumulation of physical and human capital and population growth as basic growth determinants as well as the overall tax burden as a control variable. They also report the effects of various revenue-neutral tax shifts. All economic variables are in logs. Clustered standard errors are shown in parentheses: $*$ significant at 10 per cent; ** significant at 5 per cent; *** significant at 1 per cent. 